\title{
Investigating the relationship between object relations and early maladaptive schemas with dominance and moral relations among the couples in Sanandaj
}

\author{
Afshin Salahian ${ }^{1}$, Noshin Salahian ${ }^{2}$, Hassan Gharibi ${ }^{1}$, Somayeh Saedi ${ }^{2}$, Heroo Zamani ${ }^{3}$ \\ 1-Assistant Professor, Department of Psychology, Payame Noor University, Tehran, Iran (Corresponding Author). \\ E-mail: salahian2020@gmail.com \\ 2- M.A in Educational Psychology, Department of Psychology, Payam Noor University, Tehran, Iran. \\ 3- B.A in Psychology, Department of Psychology, Payam Noor University, Tehran, Iran.
}

Received: 11/08/2020

Accepted: 04/11/2020

\begin{abstract}
Introduction: Family is the first and smallest institution in which people experience relationships with others, start relationships with other family members and learn how to communicate with other members of the community.

Aim: This study aims to investigate the relationship between object relations and early maladaptive schemas with dominance and moral relationships among the couples in Sanandaj.

Method: The current study is a descriptive-correlational one. The statistical population of this study includes all couples in Sanandaj in 2019, out of whom 150 people were selected through accessibility sampling. The participants filled in the Bell Object Relations Questionnaire (1995), Young Schema Questionnaire (2005), Huskins Dominance Adaptation Scale (1986) and Kohlberg's morality scale (1981). The collected data was analyzed using SPSS Software (version. 23).

Results: The results indicated that the sub-scales of early maladaptive schemas (i.e. abandonment, social isolation, susceptibility, difficulty, emotional restraint, stubborn criteria) and subscales of object relations (i.e. incompetence, attachment and egocentrism) were and positively associated with dominance $(\mathrm{P}<0.05, \mathrm{~T}=11.862)$. In addition, the subscales of object relations (estrangement) and subscales of early maladaptive schemas (lack of trust, difficulty and obedience) were positively associated with moral relations $(\mathrm{P}<0.05, \mathrm{~T}=4.63)$.

Conclusion: According to the results point to a positive association between object relations and early maladaptive schemas with dominance and moral relations among couples. Therefore, it can be said that object relations and early maladaptive schemas can predict dominance and moral relations among couples.
\end{abstract}

Keywords: Object relations, Early maladaptive schemas, Dominance, Moral relations

How to cite this article : Salahian A, Salahian N, Gharibi H, Saedi S, Zamani H. Investigating the relationship between object relations and early maladaptive schemas with dominance and moral relations among the couples in Sanandaj. Shenakht Journal of Psychology and Psychiatry. 2020; 7 (5): 104-116.URL: http://shenakht.muk.ac.ir/article-1-940-en.pdf

Copyright $\odot 2018$ the Author (s). Published by Kurdistan University of Medical Sciences. This is an open access article distributed under the terms of the Creative Commons Attribution-Non Commercial License 4.0 (CCBY-NC), where it is permissible to download, share, remix, transform, and buildup the work provided it is properly cited. The work cannot be used commercially without permission from the journal. 


\title{
بررسى رابطه روابط موضوعى و طر حوارههاى ناساز كار اوليه با سلطهكرى و روابط اخلاقى در زوجين شهر سندج
}

\author{
افشين صلاحيان'، نوشين صلاحيان'، حسن غريبى'، سميه ساعدى'، هيرو زمانى' \\ ا.استاديار، گروه روانشناسى، دانشكاه بيامنور، تهران، ايران (مولف مسئول). ايميل: gmail.com

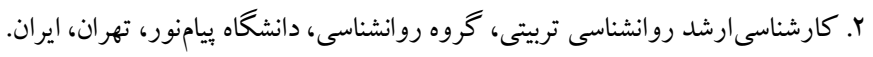

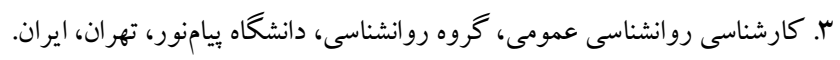

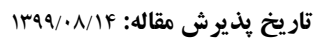

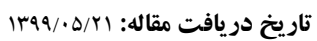

جكيده

مقدمه: خانو اده اولين و كوجهكترين نهادى است كه افراد در آن ارتباط با ديخران را تجربه مى كنند و علاوه بر آغاز ارتباط با اعضاى

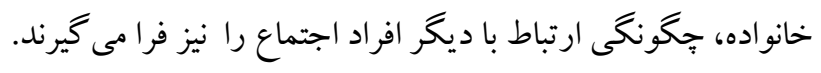

هدف: يثوهش حاضر با هدف بررسى رابطه روابط موضوعى و طرحوارههاى ناساز گار اوليه با سلطه گرى و روابط اخلاقى در زوجين شهر سنداج انجام گرفت.

روش: مطالعهى حاضر توصيفى از نوع همبستخى است. جامعهى آمارى يزوهش شامل كليهى زوجين شهر سندج در سال 19سا بود

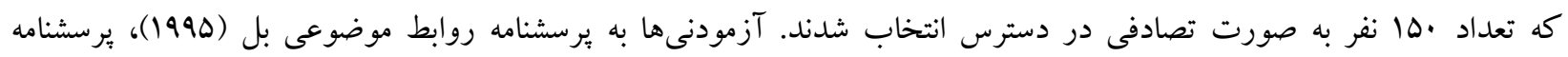

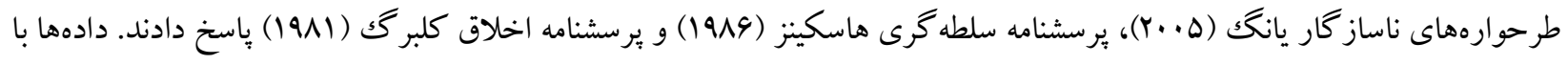

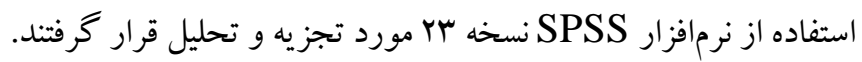

يافتهها: نتايج نشان داد كه بين زير مقياسهاى طرحواره ناساز گار (رهاشدگى، انزواى اجتماعى، آسيبذيذيرى، گرفتارى، بازدارى

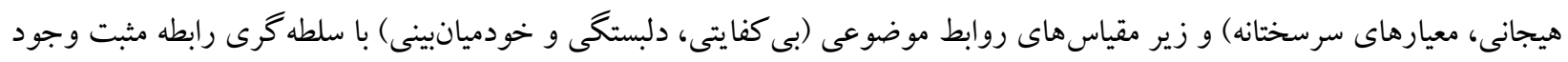

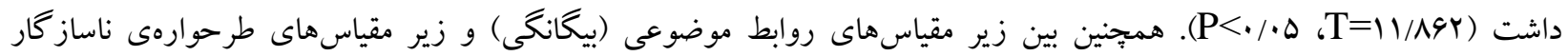

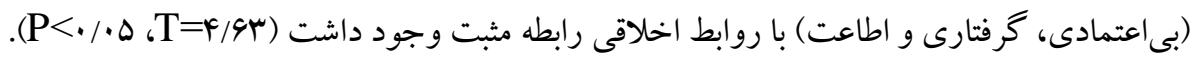

نتيجه كيرى: طبق نتايج به دست آمده از اين بثزوهش بين روابط موضوعى و طرحوارههاى ناساز گار اوليه با سلطه گرى و روابط اخلاقى در زوجين رابطه مثبت وجود داشت. در نتيجه مىتوان كفت كه روابط موضوعى و طرحوارههاى ناساز كار اوليه مى تو انند سلطه گرى و روابط اخلاقى را در ميان زوجين بيشينى نمايند. كليدوازهها: روابط موضوعى، طرحوارههاى ناساز گار اوليه، سلطه گرى، روابط اخلاقى 
ييرامون را بازنمايى مى كند. آنها بهواسطه نقش بستن ادراككهاى حسى، هيجان و اعمال در حافظه، در خلال تجارب كذشته بهويزه دوران كودكى ساخته مىشوند

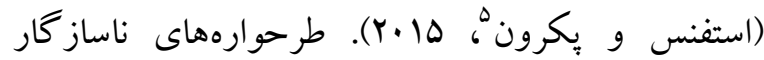
اوليه" به دليل ارضا نشدن هيجانهاى اساسى در دوران

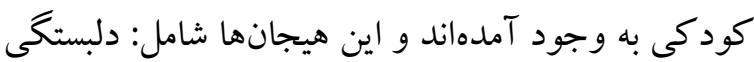
ايمن به ديخران، خود گردانى، كفايت و هويت، آزادى در بيان نيازها، خودانخيختخى و تفريح، محدوديتهاى بهري

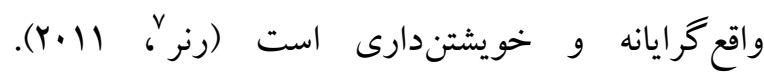
طرحوارههاى ناساز گار اوليه ادراكات، هيجانها، افكار و رفتارهاى غلط و ناكار آمد توليد مى كنند. طرحوارهها بر نحوهى تفسير رويدادها تأثير مى گذارند، فرد تجاربش را از دريجهى منفى طرحوارهها مىبيند، به طور انتخابى به

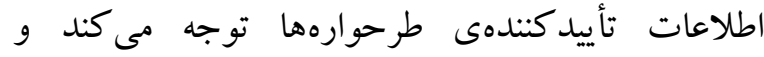

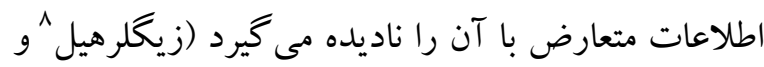
همكاران، (Y.1). يكى از مفاهيم مهم در زمينهى

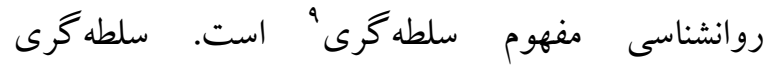
مجموعهاى از قيد و بندها و محدوديتهاى مرتبط به هم است كه با كم بينى، محدود كردن و شكل دادن مردم، شرايط فرمان بردارى و اطاعت از ديخران را فراهم مى آورد. سلطه گرى به عنوان تجربهاى از الخوهاى غالب

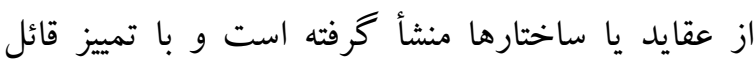
شدن، هنجار نمايى و تداوم بخشيدن به مناسبات نابر ابر و جزميات نقش در درون نظام اجتماعى صورت مى گيرد

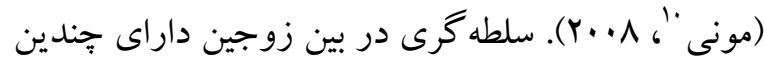
حوزنى تصميم گيرى است، بدين معنا كه در زمينهى

5 - Stephens \& Pekrun

6- Early Maladaptive Schemas

7- Renner

8 - Zeigler Hill

${ }^{9}$ - Dominance

${ }^{10}$ - Mooney

\section{مقدمه}

اصطلاح موضوع' كه وازمى تخصصى و ابداع فرويد است به هر آن جيزى اشاره دارد كه نيازى را برآورده

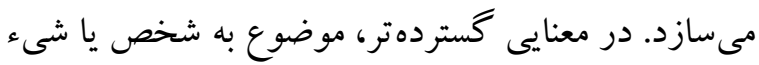
با اهميتى اشاره دارد كه موضوع يا هدف احساسات و سائقهاى يك فرد است. موضوع انكارهى ذهنى يك اهك شخص است كه با هيجان همراه است (سنت كلرّا'

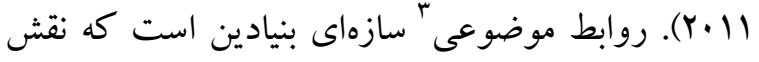
اساسى در تبين سلامت، انواع ريخت هاى آسيب شناختى و حتى ساختارهاى شخصيت دارد. روابط موضوعى را مىتوان بازنمايىهاى فرد از خود و ديخران و عواطف ماتف همراه با اين بازنمايىها تعريف كرد (خزاعى و تمدن، سهب(|)؛به عبارتى مىتوان روابط موضوعى را ظرفيت افراد براى برقرارى روابط انسانى تعريف كرد كه در

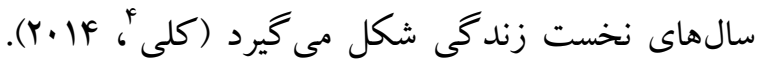
كيفيت روابط موضوعى ميراثى است كه فرد از خانواده خود به دست مى آورد كه اين ميراث سهم مهمى در توسعه ارتباطات اجتماعى فرد دارد. در تشريح روابط موضوعى بايد كفت كه به نظر مىرسد رابطهى فرد با

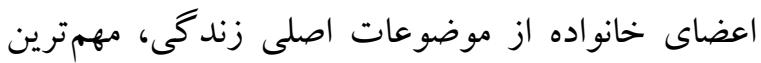
روابط، پاياترين و تأثير گذارترين روابط زندگى شخص مص است كه روابط ديخر فرد متأثر از آن است. روابط روبط موضوعى معمولاً به معناى روابط شخصى است و موضوع اصطلاحى تخصصى است به معناى آنجه سوزه با آن در ارتباط است (سنت كلر، (1) (Y). ادراكات و طرحوارههاى ما نسبت به ديخران بر روى روابط ما با افراد تأثير گذار است. طرحوارهها شيوهى ادراكك خود، ديگران و جهان

\footnotetext{
1- Object

2- Sant Clair

3 - Object Relations

${ }^{4}$ - Kelly
} 
طباطبايى، سهرابى و كريمى زارجى (اهوا() بيان كردهاند

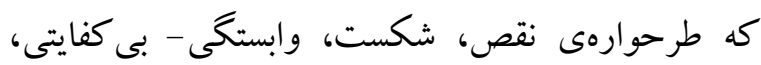
انزواى اجتماعى و محروميت هيجانى در افراد افسرده نسبت به غير افسرده از شدت بيشترى برخوردار است.

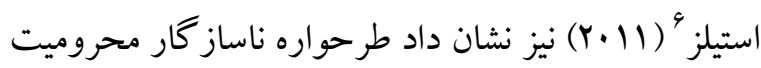
محروميت هيجانى بيشبينى كننده روابط اخلاقى است. همجنين نتايج بزُوهش رنر (11) نشان داد كه بين

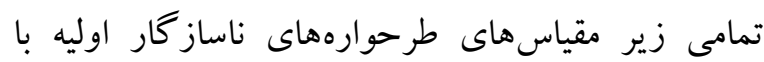
ساز گارى در بين زوجين و همجنين روابط زوجين با فرزندان رابطهى معنادار وجود دارد. در مطالعهى بشارت، دهقانى و تولاييان (سوس|) بين زير مقياسهاى طرحوارههاى ناساز گار با مشكلات زناشويى و نارضايتى

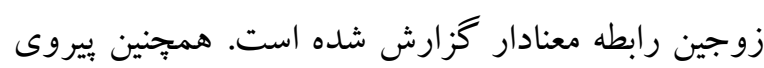
و بهرامى (49rا) و لعلزاده كند كلى، اصغرى ابراهيم آباد و حصارسرخى (Ir) نشان دادند كه بين ینج سازهى نظرى طرحوارهها (بريدگى، طرد، خود گردانى و عملكرد

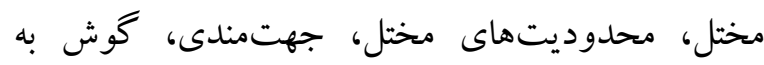
زنكى بيش از حد و بازدارى، فقط طرحو ارههاى بريدگى

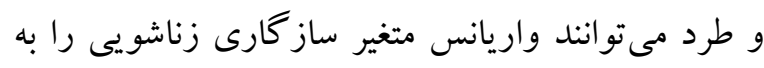
صورت معنىدارى تبيين كنند. بين طرحوارهها با طلاق عاطفى رابطهى مثبت و معنادار وجود دارد. انزواى اجتماعى، شكست در ييشرفت، محروميت هيجانى توانايى بيشبينى كنندگى طلاق عاطفى را دارند و نيز بين طرحوارههاى ناساز گار با طلاق عاطفى رابطهى مثبت و معنادار وجود دارد. طرحوارههاى انزواى اجتماعى، شكست در ييشرفت، محروميت هيجانى توانايى بيشينى كنندگى طلاق عاطفى را دارند. در مطالعهاى كه توسط رئيس الساداتى، نظربلند و خوش كنش (IraV) انجام شد

${ }^{6}$ - Stills
هزينه كردن و خريد امكانات براى خانواده و تربيت فرزندان جه كسى حرف آخر را مىزند (بارانى و و همكاران، 19 (Y). تفاوتهاى فردى بين زوجين موجب مىشود هر يكك از آنان حيطههاى خاصى را تحت سلطهى خويش درآورند. كسى كه قدرت خود را در عمل به اثبات برساند و با رعايت حرمت فرد مقابل بخشى لـ از زندگى را در اختيار مى گيرد، سلطهى خود را بر آن بخش مسجل كرده و تا بايان زندگى اين وظيفه را به عهده مى گيرد. با اين كار نه تنها مى توانند رفتار همسرشان ئن را به نحو دلخواه تغيير دهند، بلكه قادرند شخصيت او را نيز تحت تأثير قرار داده و در جهت مطلوب خود هدايت كنند، اين شيوه بر روابط اخلاقى ميان زوجين تأثير گذار

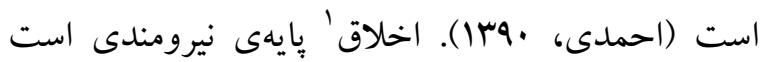
براى اينكه انسانها در توافق و همكارى با هم زندكى

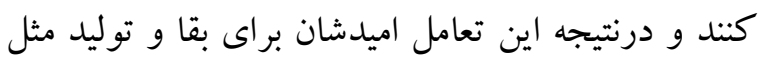

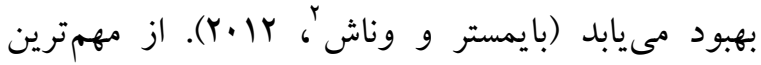
عواملى كه بر بقا، دوام و رشد خانواده اثر مى گذارد، روابط اخلاقى سالم و مبتنى بر ساز گارى و تفاهم بين اعضا بخصوص زن و شوهر است (لامكين "و همكاران، ها.Y.). اخلاق در خانواده، اصول همسردارى و داشتن روابط اخلاقى سالم در محيط خانواده از مهمترين مسائل در اسلام است. جنانجه اسلام اخلاق نيكو را عامل اصلى تحكيم بنيان خانوادهها مىداند (فرهود، ·وس|). شناسايى عواملى كه در روابط اخلاقى و عاطفى رضايتمند در بين زوجين نقش دارند، مىتواند منجر به كاهش تنشها و آسيبها در خانواده شود و به زوجين در داشتن رابطهى

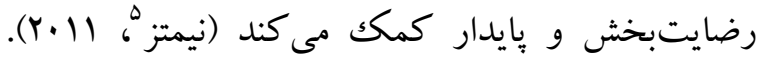

\footnotetext{
1- Ethics

2- Baumeister \& Vonasch

3 - Moral relationships

4- Lamkin

5 - Nimtz
} 
يويش، روزنو و اوين در سنتدج به عنوان نمونه يثوهش انتخاب شدند. بعد از توضيح مختصر درباره هدف يزوهش و جلب رضايت شركت كنند گان برسشنامهها در ميان آنان توزيع و تكميل شد. معيارهاى ورود به مطالعه تمايل به شركت در بيزوهش، متأهل بودن، دامنه سنى بين

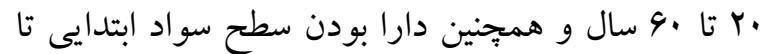
كارشناسى ارشد بود و معيار خروج از مطالعه هم شامل افرادى بود كه تمايل به شركت در مطالعه را نداشتند. دادههاى جمع آورى شده با استفاده از نرمافزار نسخه س مورد تجزيه و تحليل قرار گرفت. همجينين در

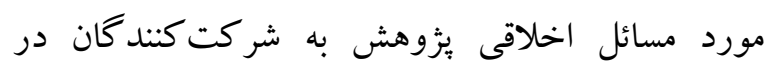
يخوهش دربارهى محرمانه بودن اطلاعات و گمنامى در تكميل ابزارها اطمينان داده شد.

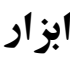
ابزارهاى مورد استفاده در اين يزوهش براى جمع آورى دادهها در ادامه به تفصيل آمده است.

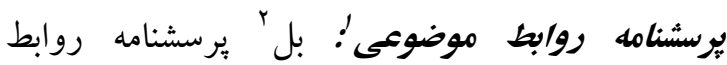
موضوعى و واقعيت آزمايى را در سال 1990 طراحى لري نمود. در اين يرسشنامه FD سؤال به سنجش روابط موضوعى و FD سؤال به سنجش واقعيت آزمايى يا

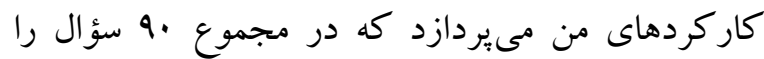
شامل مىشود. اين يرسشنامه جهار خرده مقياس بى كفايتى، خود ميان بينى و بيگانكى را شامل مى شود. در اين برسشنامه بيگانكى به كمبود اعتماد در روابط، عدم موفقيت در صميميت و ناميدى در نيل به صميميت در روابط اشاره دارد. دلبستگى نايمن، به روابط بينفردى، حساسيت به طردشدن و تأكيد بسيار زياد به اخذ تائيد

1. Thematic Relations Scale

${ }^{2}$ - Bell
به اين نتيجه رسيدند كه بين تمام حيطهاى روابط ناساز گار اوليه ارتباط معكوس و معنادار وجود داشت. روابط مناسب در جامعه بر اساس روابط مناسب در خانواده شكل مى گيرد و بهتبع آن جامعه از ثبات بيشتر برخوردار است. خانواده به يكك واحد اجتماعى - انسانى مركب از يكك يا جند فرد اطلاق مىشود كه با هدف زناشويى و توليد مثل گرد هم مى آيند و با هم وصلت مى كنند. خانواده اصل و اساس روابط درهم بيوستهاى است كه در انسانشناسى به آن نظام خويشاوندى يا اختصاراً خويشاوندى اطلاق مىشود. براى ورود به حوزه ى خانواده قدم نخستين ازدواج است. ازدواج يا زناشويى، رابطهاى است طبيعى - فرهنگى كه عموماً ميان يكك مرد و يكك زن كه به صورت عرفى يا قانونى، ارادى يا الزامى شكل مى گيرد (فكوهى، سوسا). خانو اده از جايگاه رفيعى در نظام اجتماعى برخورداراست و جّگونگى روابط بين زوجين در اين نظام اجتماعى اهميت ويزهاى دارد. با توجه به اهميت نظام خانواده و بررسى مسائل مربوط به زوجين و در صورت لزوم ييشگيرى از تنش و ايجاد روابط سالم در بين زوجين، ئزوهش در اين باره ضرورى به نظر مىرسد؛ لذا با توجه به اهميت اين موضوع، هدف

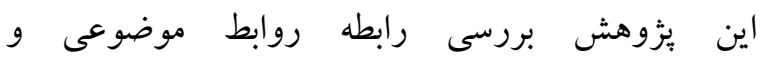

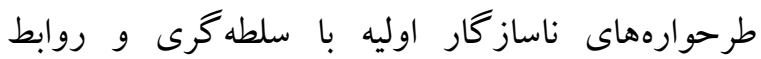
اخلاقى در زوجين شهر سنندج بود.

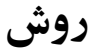

مطالعهى حاضر توصيفى از نوع همبستخى بود. جامعه

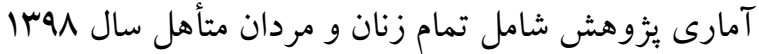
شهر سنندج بود كه تعداد •10 نفر به روش تصادفى در دسترس از بين زوجين مراجعه كننده به مراكز مشاورهى 
محاسبه مىشود. در هر كدام از طرحوارهها فرد نمرهى بيشترى كسب كند، آن طرحواره به عنوان طرحوارهى ترجيحى وى درنظر كرفته مى

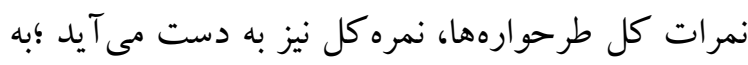
عبارتى هر آزمودنى در اين برسشنامه 19 نمره به دست مى آورد كه ها نمره مربوط به خرده مقياس ها و يكك نمره كل. در ايران ضرايب آلفاى كرونباخ براى همسانى درونى هريكك از طرحورهها در دامنهاى بين 199/ تا سم/ •

به دست آمد (آهى و همكاران، •وبr (1).

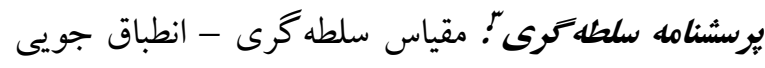
توسط كارول هاسكينز در سال 1919 ساخته شده است

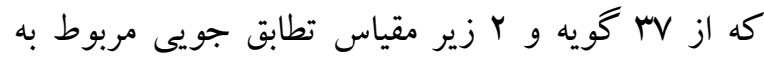
خود و تطابق جويى مربوط به همسر تشكيل شده است كه به منظور سنجش سلطه گرى - تطابق جويى در خانوادهها

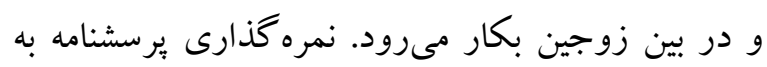
صورت طيف ليكرت ه نقطهاى است. هاسكينز (1919) نشان داد كه مقياس سلطه گرى - انطباق جويى از اعتبار نسبى تا مطلوب با ضريب آلفاى كلى AF/ · برخوردار است. عامل اول از ضريب آلفاى V9/· و عامل دوم از ضريب آلفاى 90/· برخوردار است. همجنين از روايى همزمان نسبتاً خوبى برخوردار است، بدين صورت كه بين فهردين هر دو خرده مقياس آن و جند خرده مقياس مربوط به فرم يزوهشى شخصيت شامل: خوارى طلبى، برخاشخرى،

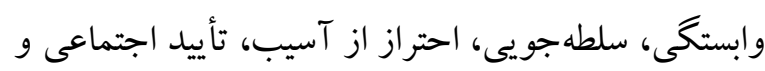
درك، همبستخى هايى وجود دارد. يرسشنامه اخلاق: برسشنامه اخلاق كلبرگك (1911) به منظور اندازه گيرى جهت گيرىهاى نوع دوستى و و قضاوت اخلاقى ساخته شده است. اين آزمون از دو

3 - Dominance Scale

${ }^{4}$ - Hoskins
ديكران مربوط مىشود. خود ميان بينى متشكل از بى اعتمادى به ديگر ان و كنترل و اعمال قدرت به ديگران است و بى كفايتى اجتماعى به خجالتى بودن، شكك و ترديد به توانايىهاى خود در برقرارى روابط (بالأخص در روابط با جنس مخالف) و ناتوانى در شكل دادن به روابط اشاره دارد. بل ضريب پيايايى مقياس روابط موضوعى را با فاصله زمانى Y هفته را بين Aه/· تا •ه/ • و با فاصله زمانى سا هفته، بين 190/ • تا 1/1/ كزارش كرده است. همجنين بل 1990 همبستخى بالايى بين مقياس روابط موضوعى و مقياس درجهبندى فشردهى روانيزشكى، مقياس نشانغان مثبت و منفى و اندازههاى فيزيولوزيكى كزارش كرده است. همجنين ويزگیىهاى روانسنجى نسخهى فارسى :يرسشنامه روابط موضوعى و واقعيت

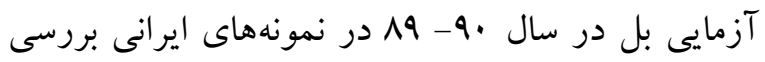

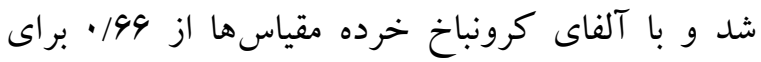
بعى كفايتى اجتماعى تا MM/ • براى بيگانكى تائيد شد.

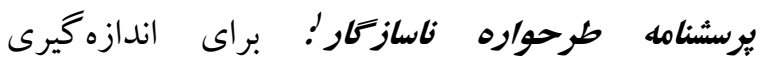

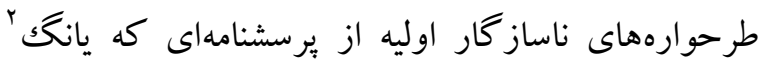

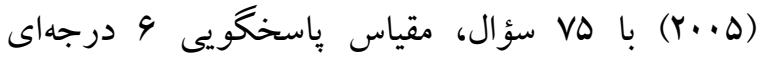
ليكرت و خرده مقياس شامل: محروميت هيجانى، طردرهاشدگى، بى اعتمادى- بد رفتارى، انزواى اجتماعى،

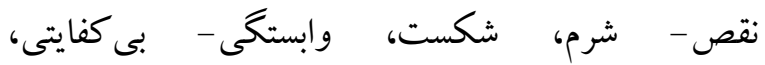
آسيب بذيرى نسبت به ضرر، گرفتارى، در دام افتادگى، اطاعت، از خود گذشتگى، بازدارى هيجانى، معيارهاى سرسختانه، استحقاق، خويشتندارى و خود انضباطى ناكافى استفاده شد. هر ينج سؤال اين برسشنامه مربوط به يكك طرحواره است و براى به دست آوردن نمرهى

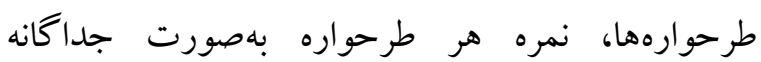

\footnotetext{
1- Early Maladaptive Schemas Scale

${ }^{2}$ - Young
} 
بررسىهاى متعدد از AF/ • تا AF/ متغير بوده است. بايايى قسمت دوم اين آزمون A4/ • است.

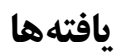

نمونهى حاضر در اين ئزوهش را •ها نفر از افراد متأهل ساكن شهر سنندج در دامنهى سنى بين ·Y تا •9 سال و سطح تحصيلات سم نفر داراى سواد ابتدايى، 99 نفر سواد مقطع دبيرستان، وب نفر كارشناسى و ها نفر كارشناسى ارشد بودند. ميزان همبستخى بين خرده مقياسهاى طرحوارههاى ناساز كار با سلطه گرى در جدول ا آمده
قسمت تشكيل شده است كه قسمت اول آن ميزان نوع دوستى و قسمت دوم آن سطح تحول اخلاقى را مىسنجد. در اين آزمون سه معما مطرح مىشود. اين معماها هر كدام يكك موقعيت دارند و هر معما به دو قسمت تقسيم مىشود. هر قسمت سؤ الهاى مخصوص به خود را دارد و در عين حال سؤالهاى قسمت اول با يكك كايك مقياس جند درجهاى از كاملاً بله تا كاملاً نه درجهبندى شدهاند. همجينين سؤالهاى قسمت دوم آزمون كه سطح اخلاقى فرد را مىسنجد از يك مقياس هـ درجهاى از خيلى زياد تا خيلى كم قرار دارند. طبق يثزوهش مير

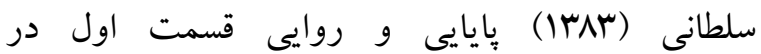

جدول ا همبستكى بين خرده مقياسهاى طرحوارههاى ناساز كار با سلطهرى

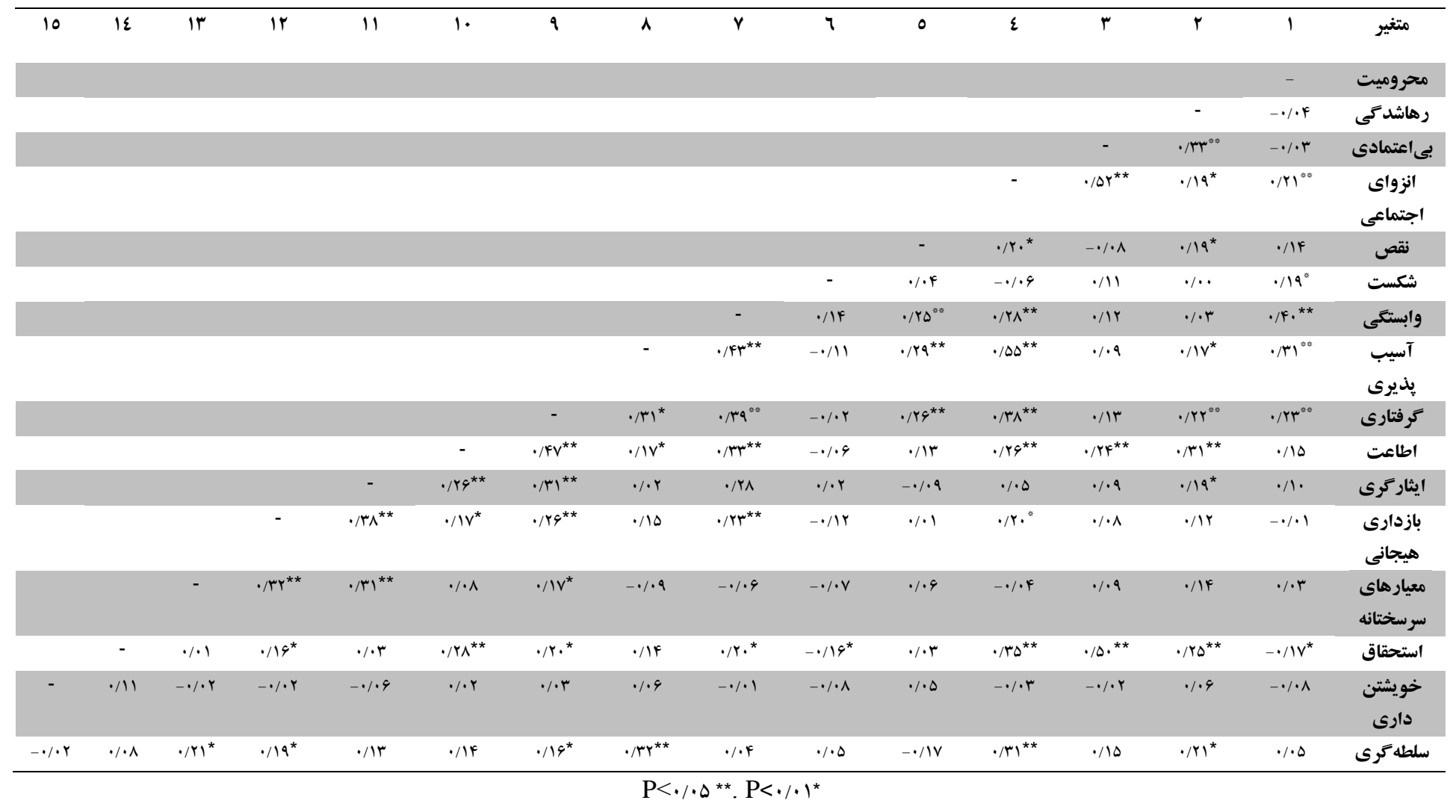

نتايج به دست آمده بين رها شدگى انى، انزواى اجتماعى،

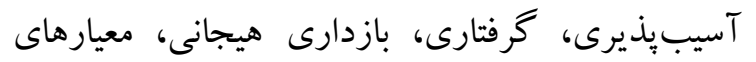

در جدول | همبستگى بين خرده مقياسهاى طر حوارههاى ناساز گار با سلطه گرى ارائه شده است. طبق 
كرفتارى، بازدارى هيجانى، معيارهاى سرسختانه) سطح

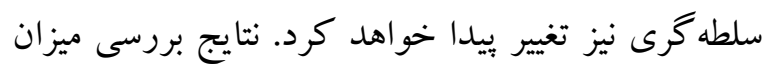

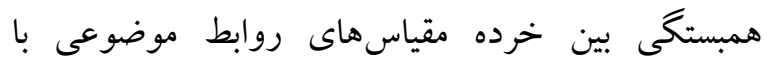
سلطه گرى نيز در جدول ب آمده است.
سر سختانه با سلطه گرى همبستخى مثبت و معنادارى وجود داشت (P>•/P). مثبت بودن رابطهى بين اين متغيرها

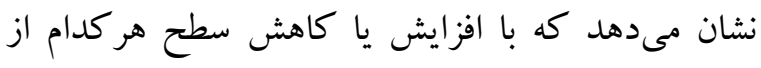

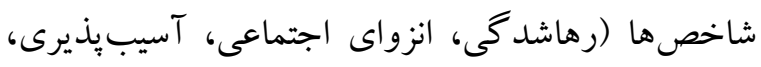

\begin{tabular}{|c|c|c|c|c|c|c|}
\hline \multirow[t]{6}{*}{7} & 0 & $\varepsilon$ & $r$ & $r$ & 1 & متغير \\
\hline & & & & & - & سلطه Fىى \\
\hline & & & & - & $\cdot / \mathrm{V}^{\star \star}$ & تطابق با خود \\
\hline & & & - & $\cdot / r V^{* *}$ & $\cdot / A r^{\star \star}$ & تطابق با همسر \\
\hline & & - & $-\cdot 1 \cdot \mathrm{V}$ & $\cdot / \Delta \varphi^{\star *}$ & $\cdot / r \Lambda^{\star \star}$ & بى كفايتى \\
\hline & - & $\cdot / \Lambda F^{\star \star}$ & $-\cdot / \cdot \Delta$ & $\cdot / F V^{* *}$ & $\cdot / Y F^{\star *}$ & خودميانبينى \\
\hline- & $\cdot / M V^{\star \star}$ & $\cdot / M F^{* *}$ & $\cdot / \cdot \Delta$ & $\cdot / Y F^{\star *}$ & $\cdot / 1 V^{\star *}$ & دلبستغى \\
\hline$\cdot / F r^{* *}$ & $\cdot / F r^{* *}$ & $\cdot / r F^{\star \star}$ & $\cdot / \cdot \Delta$ & $\cdot / \cdot F$ & $\cdot / \cdot \Delta$ & ييكانگى \\
\hline
\end{tabular}

افزايش و كاهش در سطح هركدام از شاخصهاى

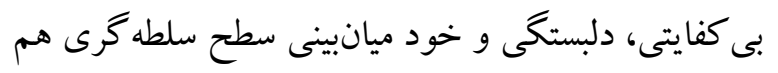

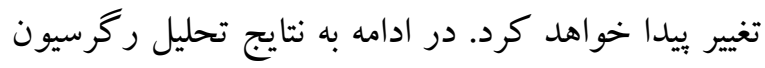
در جدول باشاره مى كنيم.
در جدول r نتايج همبستخى بين خرده مقياسهاى روابط

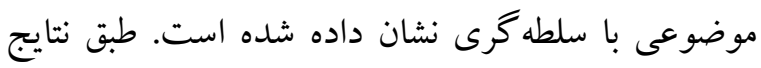

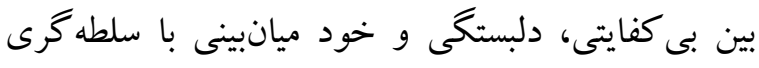

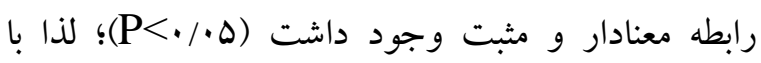

جدول ب ضرايب استاندارد و غير استاندارد متغيرهاى بيشيين

\begin{tabular}{|c|c|c|c|c|c|}
\hline سطح معنادارى & $\mathbf{T}$ & Beta & خطاى استاندارد & B & مدل \\
\hline$\cdot / \ldots$ & II/AGY & - & r/VYA & $F F / Y \mid q$ & ضريب ثابت \\
\hline$\cdot / \cdot r$ & $r / 19$. & - /YAF & $\cdot / M Y$ & $\cdot /$ rAl & آسيب \\
\hline$\cdot / \cdots$ & $r / v \Lambda$. & $\cdot / r V$ & $\cdot /|F|$ & $\cdot / \Delta \Delta V$ & معيار \\
\hline$\cdot / \cdot r$ & $-r / l \Delta r$ & - & $\cdot / \cdot 19$ & $-\cdot / T V H$ & نقص \\
\hline.$/ .10$ & $r / 49$. & $\cdot / r \cdot 1$ &.$/ 191$ & • & انزوا انزوا \\
\hline.$/ .14$ & $r / q V G$ & . /AT & . /MF & r & بع كفايتى \\
\hline.$/ . \pi \mu$ & $r / 100$ & $\cdot / 10 F$ &.$/ .41$ & $\cdot / 1 \cdot 4$ & شكست \\
\hline
\end{tabular}

در جدول r خلاصه يافتهاى رگرسيون سلسله مراتبى رابطه معنادارى داشتند. نتايج بررسى ميزان همبستخى بين

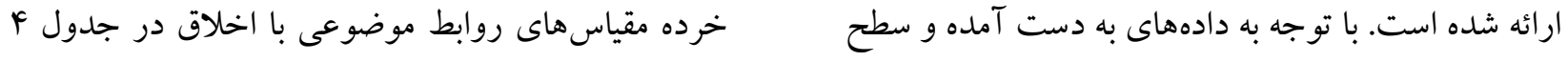

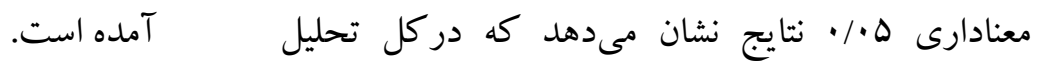

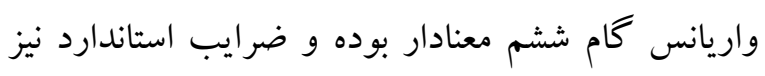




\begin{tabular}{|c|c|c|c|c|c|c|c|c|}
\hline \multirow[t]{8}{*}{$\Lambda$} & $r$ & 7 & 0 & $\varepsilon$ & $r$ & $r$ & 1 & متغير \\
\hline & & & & & & & - & خود ميانبينى \\
\hline & & & & & & - & $\cdot / \Lambda k^{* *}$ & بى كفايتى \\
\hline & & & & & - & $\cdot / Y F^{* *}$ & $\cdot / f r^{* *}$ & بيكانكى \\
\hline & & & & - & $\cdot / F Y^{* *}$ & $\cdot / \mu F^{* *}$ & $\cdot / r v^{* *}$ & دلبستكى \\
\hline & & & - & $-\cdot / 10$ & $-\cdot / 10$ & $-\cdot 1 \cdot 9$ & $\cdot / \cdot r$ & يِيش قراردادى \\
\hline & & - & $\cdot / r \Lambda^{* *}$ & $\cdot / 1$ & $\cdot / \cdot r$ & $\cdot / 1 r$ & $\cdot / \cdot 1$ & انتظارات متقابل \\
\hline & - & $\cdot / 14$ & $\cdot / r \wedge^{* *}$ & $-\cdot / Y F^{* *}$ & $-\cdot / \cdot r$ & .1 .9 & .1 .9 & وجدان و اصول اجتماعى \\
\hline- &.$/ .9$ & $\cdot / r \wedge^{\star *}$ &.$/ .9$ & $\cdot / r$ &.$/ I F$ & $-\bullet / 1$ & $-\cdot 1 \cdot 9$ & يس قراردادى \\
\hline$\cdot / F F^{* * * \sigma^{*}}$ & $\cdot / \mu \cdot * \star$ & $-\cdot / q^{* *}$ & $-\cdot / \Delta r^{* *}$ & $-\cdot / \cdot r$ & $\cdot / 14^{* *}$ & $-\cdot / \cdot v$ & $-\cdot 1 \cdot 9$ & اخلاق كل \\
\hline
\end{tabular}

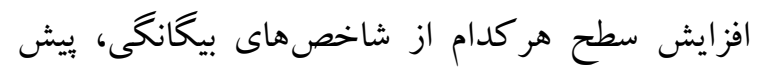

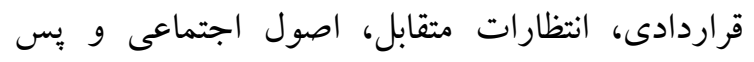
قراردادى ميزان سطح اخلاق نيز تغيير بيدا خواهدكرد.

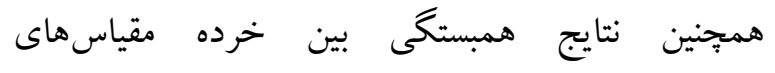
طرحوارههاى ناساز كار با اخلاق در جدول هـ همده است
در جدول \& همبستخى بين خرده مقياسهاى روابط موضوعى با متغير اخلاق ارائه شده است. نتايج نشان

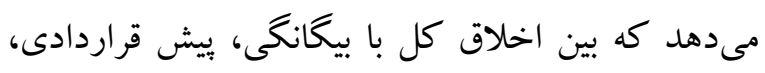

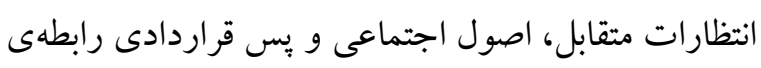

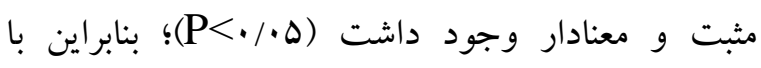

جدول 0 همبستغى خرده مقياسهاى طرحوارههاى ناساز

\begin{tabular}{|c|c|c|c|c|c|c|c|c|c|c|c|c|c|c|c|}
\hline 10 & $1 \varepsilon$ & ir & it & 11 & 1. & 9 & $\wedge$ & r & 7 & 0 & $\varepsilon$ & $r$ & $r$ & 1 & متغير ها \\
\hline & & & & & & & & & & & & & & - & اخلاق كل \\
\hline & & & & & & & & & & & & & - & $-\cdot / \cdot F$ & محروميت \\
\hline & & & & & & & & & & & & - & $-\cdot / \cdot f$ &.$/ 1$ & رهايى \\
\hline & & & & & & & & & & & - & • & $-\cdot / \cdot r$ & $\cdot / r \Delta^{* *}$ & بى اعتمادى \\
\hline & & & & & & & & & & - & $\cdot / \Delta r^{* * *}$ &.$/ 19^{*}$ & $\cdot /\left.r\right|^{* *}$ &.$/ 10$ & انزوا \\
\hline & & & & & & & & - &.$/ F$ & -.1 .4 &.$/ 11$ & $\cdot / \cdot \Delta$ &.$/ 19^{*}$ & $-\cdot / \cdot r$ & شكست \\
\hline & & & & & & & - & $\cdot / l f$ & $\cdot / r \Delta^{* *}$ & $\cdot / r \Lambda^{* *}$ & $\cdot / r$ &.$/ . r$ & $\cdot / 4 \cdot * *$ & $\cdot / \cdot \Delta$ & وابستغى \\
\hline & & & & & & - & $\cdot / \mu \mu^{* *}$ & $-\cdot / 11$ & $\cdot / r q^{* *}$ & $\cdot / \Delta \Delta^{* *}$ &.$/ .9$ & $\cdot / / V^{*}$ & $\cdot / \mu 1^{* *}$ & $\cdot / r$ & آسيب \\
\hline & & & & & - & $\cdot /\left.\pi\right|^{* *}$ & $\cdot / \mu q^{* *}$ & $-\cdot / \cdot r$ & $\cdot / r 4^{* *}$ & $\cdot / r \Lambda^{* *}$ & r & $\cdot / r r^{*}$ & $\cdot / r r^{* *}$ & $\cdot / 19^{*}$ & كرفتارى \\
\hline & & & & - & $\cdot / F v^{* *}$ & $\cdot / 1 V^{*}$ & $\cdot / \mu^{* *}$ & -.1 .9 & ./T & $\cdot / r 4^{* *}$ & $\cdot / r F^{* *}$ & $\cdot /\left.\pi\right|^{* *}$ & $\cdot / 10$ & $\cdot / r F^{* *}$ & اطاعت \\
\hline & & & - & $\cdot / r 4^{* *}$ & $\cdot /\left.\pi\right|^{* *}$ & $\cdot / \cdot r$ & $\cdot / \cdot r$ & $\cdot / \cdot r$ & -.1 .9 & $\cdot / \cdot \Delta$ & $1 / 9$ &.$/ 19^{*}$ & $\cdot / 1$ & $-\cdot / \cdot V$ & ايثارگرى \\
\hline & & - & $\cdot / \Gamma \Lambda^{* *}$ & $\cdot / I V^{*}$ & $\cdot / r 9^{* *}$ &.$/ 10$ & $\cdot / r^{* *}$ & $-\cdot / 1 r$ & $\cdot / \cdot 1$ & $\cdot / r \cdot{ }^{*}$ & $\cdot / \cdot \wedge$ & $\cdot / r$ & $-\cdot / \cdot 1$ & .1 .9 & هيجانى \\
\hline & - & $\cdot / r Y^{* *}$ & $\cdot /\left.\mu\right|^{* *}$ & $\cdot / \cdot 1$ & $\cdot / I V^{*}$ & $-\cdot / \cdot 9$ & -.1 .4 & $-\cdot / \cdot V$ & .1 .9 & $-\cdot / \cdot f$ &.$/ \cdot 9$ & $\cdot / I F$ & $\cdot / \cdot r$ & $\cdot / 10$ & سريار هاى \\
\hline- & $\cdot / \cdot 1$ &.$/ 19^{*}$ &.$/ \cdot r$ & $\cdot / \mathrm{r}^{* *}$ & $\cdot / r^{*}$ &.$/ f F$ & $\cdot / r^{*}$ & $-.119^{*}$ & $\cdot / \cdot r$ & $\cdot / r \Delta^{* * *}$ & $\cdot / 0 \cdot * *$ & $\cdot / r \Delta^{* *}$ & $-\cdot / 1 V^{*}$ & $\cdot / r$ & استحقاق \\
\hline.$/ 11$ & $-\cdot / \cdot r$ & $-\cdot / \cdot r$ & -.1 .4 &.$/ \cdot r$ & $-.1 \cdot 9$ & $\cdot / \cdot v$ & $-\cdot \cdot \cdot 1$ & $-\cdot \cdot \cdot \wedge$ & $\cdot / \cdot \Delta$ & $-\cdot / \cdot r$ & $-\cdot / \cdot r$ & -.1 .9 & $-\cdot / \cdot \wedge$ & $\cdot / 10$ & خويشتن \\
\hline
\end{tabular}

$\mathrm{P}<\cdot / \cdot$ ه $\left.^{* * *} . \mathrm{P}<\cdot / \cdot\right)^{*}$ 
كاهش سطح هركدام از شاخصهاى بىاعتمادى، كرفتارى و اطاعت ميزان سطح اخلاق نيز تغيير بيدا

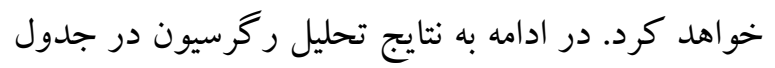
9 اشاره مى كنيم.
جدول ه نتايج همبستكى طرحوارههاى ناساز كار با اخلاق را نشان مىدهد. نتايج همبستخى نشان مىدهد كه بين اخلاق با بىاعتمادى، گرفتارى و اطاعت رابطه مثبت و معنادارى وجود داشت (ه•/P>)؛ لذا با افزايش يا

\begin{tabular}{|c|c|c|c|c|c|}
\hline \multicolumn{6}{|c|}{ جدول 7 جدول ضرايب استاندارد و غير استاندارد } \\
\hline سطح معنادارى & $\mathbf{T}$ & Beta & خطاى استاندارد & B & مدل \\
\hline$\cdot / \cdot \cdot 1$ & r/FF & $\cdot / r \cdot \Lambda$ & $\cdot 1 \cdot 09$ & $\cdot / 194$ & بى اعتمادى \\
\hline$\cdot / \cdot v$ & Y/NQ & $\cdot / r Y$ &.$/ \cdot 41$ & $\cdot / 11 \mathrm{r}$ & اطاعت \\
\hline.$/ .19$ & $r / r V$ & $\cdot /$ MAF &.$/ \cdot 11$ &.$/ .4 r$ & 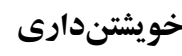 \\
\hline$\cdot / \cdot$ Y4 & $-Y / Y \Delta$ & $-\cdot / r \cdot \Delta$ &.$/ .49$ & $-\cdot / 114$ & استحقاق \\
\hline$\cdot / \ldots$ & $r / 9 \pi$ & & / AYY & $F / T V$ & 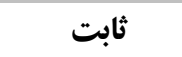 \\
\hline
\end{tabular}

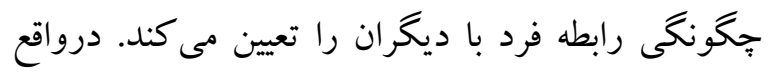
اين الخوهاى بايدار درونى، تعيين كنندهى كيفيت

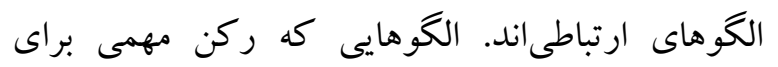

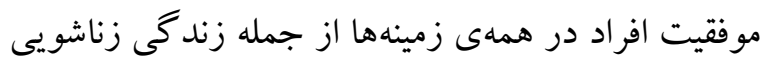

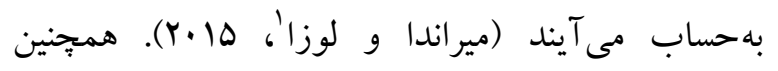

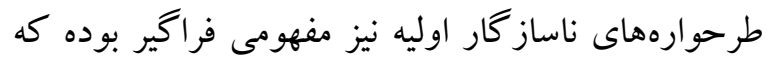
جنبههاى گوناگونى از زندگى و شخصيت فرد را تحت تأثير خود قرار مىدهد. از جمله حيطههايى كه انتظار مىرود اين طرحوارهها اثر كذار باشند، ارتباط آن با نه مسائل و مشكلات در روابط بين زوجين است

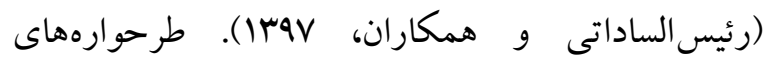
ناساز كار كه در كود كى شكل مى گيرند مى تواند كه يك انديشهى غلو آميز از توانمندى را در فرد به وجود بياورند؛ مانند انديشه كنترل و تسلط بر رفتار همسر كه مىتواند جنان شدت بيدا كند كه تبديل به يكك تصور غلط در مورد توانمندى براى تغيير و تسلط بر همسر شود. بدين

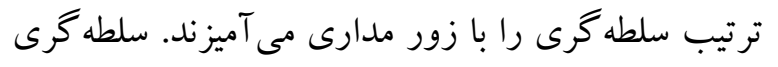

در جدول 9 خلاصه يافتهاى ركرسيون سلسله مراتبى ارائه شده است. با توجه به دادههاى به دست آمده و سطح معنادارى هـ/• نتايج ضريب استاندارد متغيرهاى ييشبين

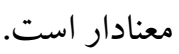
هدف يثزوش حاضر بررسى رابطه روابط موضوعى و

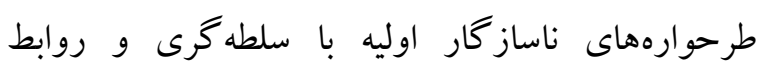
اخلاقى در زوجين شهر سنتدج بود. نتايج يزوهش نشان داد كه بين روابط موضوعى و طرحوارههاى ناساز گار اوليه با سلطه گرى در زوجين روابط معنادار وجود دارد

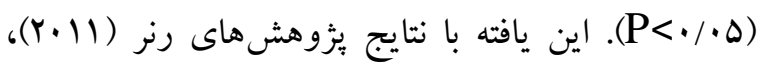

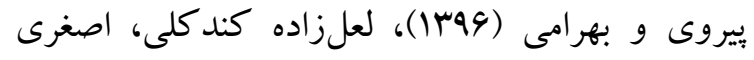
ابراهيم آباد و حصارسرخى (IR (IF) و بشارت، دهقانى و تولاييان (سوسا) همسو است. در تبيين اين يافته مىتوان كفت كه روابط موضوعى بازنمايىهاى فرد از ديخران و

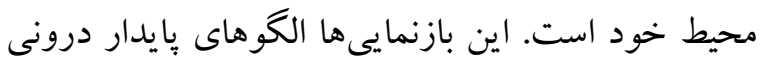
هستند كه در موقعيتهاى ارتباطى فعال مىشوند و

\footnotetext{
${ }^{1}$ - Miranda \& Louza
} 
زوجين و تعالى خانو اده نقش بديهى و انكارنايذير دارد. به طور معمول، زوجينى كه روابط عميق، منطقى و دوستانه را تجربه مى كند زندگى زناشويى موفقترى خواهند

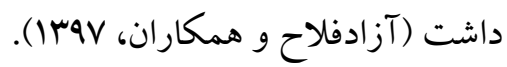

\section{نتيجه كيرى}

با توجه به يافتهاى حاصل از اين يُروهش مىتوان نتيجه كرفت كه קنانجه زندگى زناشويى شرايط نامساعد را براى ارضاى نيازهاى مختلف همسران ايجاد كند، نه تنها جنبههاى مثبت ازدواج تحقق نمى يابد، بلكه اثرات منفى و

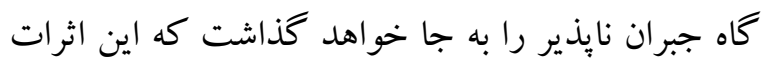
منفى نه تنها باعث بروز مشكل در روابط بين زوجين و بروز اختلال در روابط ميان آنان مىشود، بلكه منجر به به به بردي ايجاد مشكلاتى براى فرزندان نيز خواهد شد و فرزندان نيز از روابط بين زوجين (يدر و مادر) متأثر خواهند شد. افراد در برابر روابط خود با خانواده، مسئوليت خطيرى دارند و بايد در شيوه روابط با ديخران و افراد خانواده طرز تفكر نسبت به خود و خانواده خود و نوع برخو ردد و روابط اخلاقى و عاطفى با آنان مراقبت نمايند. با توجه به به اهميت عوامل روانشناختى مورد بررسى در اين بُزوهش و ميزان تأثير كذارى كه اين عوامل در زندكى زورجين دارند، بايد بيش از بيش به شناخت و كنترل آنها يرداخته شود. شناخت و كنترل اين عوامل روانشناختى مى تواند باعث ايجاد روابط سالم ميان زوجين و درنتيجه داشتن خانواده سالم و در ادامه جامعهاى سالم و كار آمدتر شود. اينكه افراد در آينده، شخصيتى متعادل و آرام داشته باشند يا شخصيتى نا آرام و يرخاشكر، با ديخر افراد جامعه اندانها

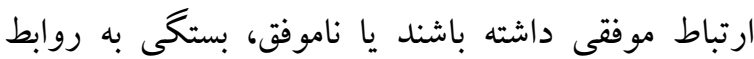
درون خانواده دارد؛ بنابراين نقش زوجين در ايجاد روابط
محصول هنجارهاى اجتماعى، قوانين و مفروضات يذيرفته شده است و براى تداوم آن بايد اقدام تعادلى در هرئ قدرت نهادينه شده وجود داشته باشد. سلطه گرى در خانواده از زن و شوهر آغاز شده و با به دنيا آمدن فرزندان به سمت آنان نيز كشيده مىشود (احمدى،

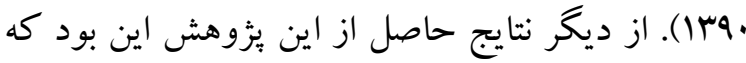
بين روابط موضوعى و طرحوارههاى ناساز كار اوليه با بائ روابط اخلاقى در زوجين روابط معنادارى وجود دارد

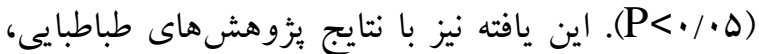

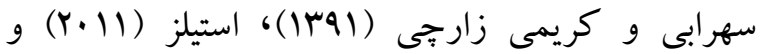

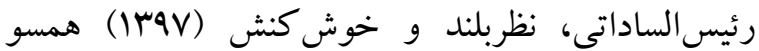
است. در توجيه اين يافته نيز مىتوان كفت كه

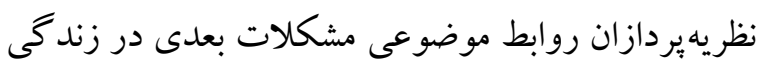
زناشويى را متأثر از روابط اوليهى كودكك تعبير مى كنند (واحدى و همكاران، الجا). از ديدكاه روابط ابثره، توانايى برقرارى روابط ارضا كننده متقابل در زندگى تا حدودى به الكوى درونى شده ناشى از تعاملات اوليه برمى گردد كه بر روى روابط درون خانوادگى فرد در آينده تأثير گذار خواهد بود (برس و و همكاران، با.ب). همجنين طرحوارههاى ناساز كار اوليه نيز در افراد به تجربهى رويدادهاى منفى در زندگى منجر مىشود و

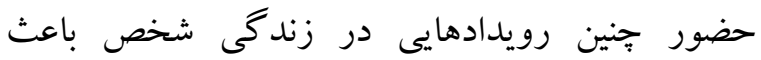
احساس فنار روانى بيش از حد و نارضايتى از زندگى

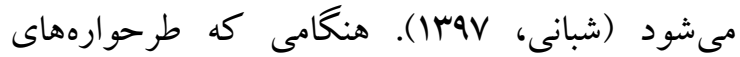
ناساز كار فعال شوند، سطوحى از هيجان منتشر مىشود و مستقيم يا غيرمستقيم منجر به ايجاد تعارضات بين فردى مىشود و بر روابط بين افراد تأثير خذار است (هالجين؛ 1 •r(Y). روابط اخلاقى و عاطفى در يويايى و سلامت روتين

\footnotetext{
1 - Bers
}

2- Halichin 
Baumeister R, Vonasch A. (2012). Is the essence of morality mind perception, self- regulation, free will, or culture?. Psychological Inquiry, 23, 134-136.

Bell MD. (1986). A Scale for the assessment of object relations: Reliability, validity, and factorial invariance. Journal of Clinical Psycho, 42,73341.

Bers SA, Besser A, Harpaz I, Blatt SJ. (2013). An empirical exploration of the dynamics of anorexia nervosa: Representations of self, mother and father. Psychoanalytic Psychology, 30, 188-199.

Besharat MA, Dehghani S, Tavalaeyan M. (2014). Mediating role of early maladaptive schemas on the relathionship between parenting styles and marital problems. Journal of Family Psychology, 1, 3-18. (In Persian)

Fakohi N. (2012). An Introduction to Anthropology: Tehran: Nai Publication. (In Persian)

Farhood D. (2011). Ethics education. University of Medical Sciences, Tehran. (InPersian)

Halichin R, Susan C. (2018). Psychological Pathology: Clinical Perspectives on DSM-Related Psychiatric Disorders. Translation: Yahiya Sayed Mohammadi. Tehran: Ravan Publication. (In Persian)

Huskins CN. (1986). Measuring Perceived dominanceaccommodation: Development of a scale, Psychological Reports, 58, 627-642.

Kelly FD. (2014). The Assessment of object Relations Phenomena in Adolescents: TAT and Rorschach Measures. London: Rutledge.

Khazaee Z, Tamadon F. (2014). John Martin Fishers Viewpoint regarding the necessary free will in moral responsibility. Journal of Hekmat VA Falsafe, 3, 131-151. (In Persian)

Kohlberg L. (1981). Global Rating Guide with new materials. School of Education, Harvard University.

Laal Zade A, Asghari M, Hesar Sorkhi R. (2014). The role of maladaptive schemas in the divorce emotionally. Journal of Clinical psychology, 7 : 23-38. (In Persian)

Lamkin J, Keith, W, Campbell R, Vanderlin D. (2015). AN exploration of correlates of grandiose and

$$
\begin{aligned}
& \text { سالم در خانواده بسيار تأثير گذار خواهد بود. انجام } \\
& \text { بزوهش حاضر با محدوديتهايى همراه بود: يكى از } \\
& \text { محدوديتهاى يزٔوهش حاضر اين است كه ماهيت طرح } \\
& \text { يثزوهش حاضر از نوع همبستخى است و به صورت } \\
& \text { مقطعى اجرا شده است؛ بنابراين، اسناد مطرح شده } \\
& \text { نمى توانند الزاماً علت شناختى تلقى شوند. همبِين نمونه } \\
& \text { ى مورد بررسى در اين ئزوهش يكك نمونه از زوجين } \\
& \text { ساكن شهر سنندج بودند، اين محدوديت قابليت تعميم } \\
& \text { نتايج را محدود مى كند. } \\
& \text { سياسگز ارى } \\
& \text { از همكارى صميمانهى تمامى كسانى كه در انجام اين } \\
& \text { يثزوهش ما را يارى نمودند، كمال تشكر را داريم. } \\
& \text { يزوهش حاضر از نتايج طرح تحقيقاتى مصوب كميته } \\
& \text { تحقيقات دانشجويى دانشگاه بيام نور تهران با كد } \\
& \text { IR.PNU.REC.1398.023 مىباشد. }
\end{aligned}
$$

\section{References}

Ahee Gh, Mohammadifar MA, Besharat, M. A. (2011). Reliability and Validity of the Young schema questionnaire. Journal of Psychology, 3, 5-25. (In Persian)

Ahmadi A. (2011). The psychology of the family. Tehran: Nai Publication. (In Persian)

Azadfalah P, Ahmadi SH, Farahani H. (2019). Find the dominant communication patterns of Iranian couples based on communication conflict. Joumal of Clinical Psychology Studies, 32, 6792. (In Persian)

Barani M, Zarei E, Falahchai R. (2016). Investigating the relationship between self- esteem and family power structure among women seeking divorce in Bandar Abbas. Journal of Women and Family Studies, 31, 23-37. (In Persian) 
vulnerable narcissism in romantic relationships: Journal of Nurse Educe Today, 79, 166-171.

Miranda B, Louza MA. (2015). The physician's quality of life: Relationship with ego defense mechanisms and object relation. Comprehensive psychiatry, 63, 9-22.

Mirsoltani B. (2004). Investigating and comparing the moral development of delinquent adolescents and normal adolescent. M.A thesis, Faculty of Humanities. (In Persian)

Mooney M. (2006). A critique of Freire's perspective on critical social theory in nursing education, Journal of Nurse Educe Today, 3: 240-244.

Nimtz MA. (2011). Satisfaction and contributing factors in satisfying long- term marriage: A phenomenological study A doctoral dissertation in psychology. Liberty University.

Pairavi M, Bahrami H. (2017). The relationship between Early Maladaptive Couples Schemas and Marital Adjustment in Married Students of Tehran Science Research Unit. Journal of Development Psychology. 1,131-158. (In Persian)

Raies Sadati F, Nazarboland N, Khoshkonesh A. (2017). The Study of the Relation of Early Maladaptive Schemas and Differentiation with the Extent of Marital Adjustment. Journal of Disability Studies,6, 28-35. (In Persian)

Renner F. (2011). Early maladaptive schemas in depressed patients: Stability and relation with depressive symptoms over the course of treatment. Journal of Affective Disorders, 23, 63-82.

Sant Clair M. (2011). An Introduction to thematic relationship and psychology itself. Translation: Tahmaseb A, Aghaee, A. Tehran: Nai Publication.

Shabani J. (2018). Expectant Anxiety Test Based on Early Maladaptive Schemas in Secondary Psychology School Students in Gorgan, 4, 4757. (In Persian)

Stephens E, Pekrun M. (2015). Selfenhancing and selfdefeating ego orientation: Relations with task and avoidance orientation, achievement, selfperception and anxiety. Journal of Educational psychology, 89, 71-81.
Stiles OE. (2011). Early maladaptive schemas and intimacy in young adult's romantic relationship. [unpublished doctoral dissertational]. San Francisco, USA: Alliant international University.

Tabatabai S, Sohrabi S, Karimi F, Zarei M. (2012). The Effectiveness of Training in Emotional Schema Therapy Techniques on the Schema of Depressed People. Journal of Psychology. 11,75-86. (In Persian)

Vahedi A, Makvand SH, Bigdeli I. (2012). Diagnosis of Higher Level Personality Pathology by Using Short- Term Dynamic Psychotherapy. Joumal of Clinical Psychology, 4, 15-28. (In Persian)

Young JE, Klosko JS, Weishaar ME. (2005). Schema therapy: A practitioners Guide. New York: The Guilford press.

Zeigler Hill V, Green BA, Arnau R, Sisemore T, \& Myers EM. (2011). Trouble ahead, trouble behind: Narcissism and early maladaptive schemas. Journal of Behavior Therapy and Exprimental Psychiatry, 42, 96-103. 